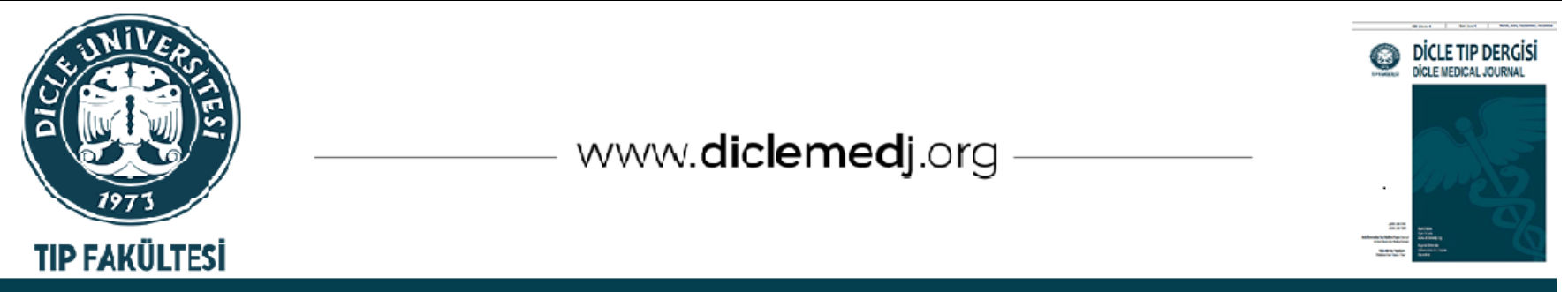

Original Article / Özgün Araştırma

\title{
Peripheral Silent Period In Cervical and Generalized Dystonia
}

\author{
Melih Tutuncu ${ }^{D}$ 1, Hikmat Abbaszade ${ }^{i}{ }_{1}$, Aysegul Gunduz ${ }^{D}$ 1, Meral E. Kiziltan ${ }^{1} 1$ \\ 1 Department of Neurology, Cerrahpasa Medical Faculty, Istanbul University-Cerrahpasa, Istanbul, Turkey \\ Received: 14.02.2021; Revised: 01.03.2021; Accepted: 01.03.2021
}

\begin{abstract}
Objective: Dystonia is a movement disorder described by continuous or alternating muscle contractions causing unusual postures or insistent motions. Abnormal sensorimotor integration and abnormalities in inhibitory pathways are thought to have a role in pathogenesis. This paper aims to research the state of inhibitory pathways in the spinal cord in dystonia through documenting a silent period (SP) through cutaneous stimulation (CuSP) or mixed nerve stimulation (MnSP).
\end{abstract}

Methods: 23 patients with dystonia were included in the study. Also, 19 healthy subjects were included in the study as a control group. Ages were similar between two groups. ( $\mathrm{p}=0.092)$. CuSP and MnSP are recorded through abductor pollicis brevis and median nerve at the wrist respectively.

Results: Onset latency, time, and suppression index of CuSP were equivalent between two groups. Moreover, the initiation and terminate latencies of $\mathrm{MnSP}$, also duration, were similar between these two groups. I2 suppression index was lower in generalized dystonia patients compared to patients with cervical dystonia $(100.0$ vs $86.7 \pm 21.4 \%$; $F=4.252$, 0.035).

Conclusions: The most striking result to emerge from the data is that there was lower suppression during CuSP in generalized dystonia patients. Our results suggest that spinal inhibitory circuits are less active if only there is clinical involvement of the relevant segment.

Keyword: Dystonia, Cutaneous silent period, mixed nerve silent period

DOI: $\mathbf{1 0 . 5 7 9 8 / d i c l e t i p . 8 8 8 7 8 1}$

Correspondence / Yazıșma Adresi: Melih Tutuncu, Department of Neurology, Cerrahpasa Medical Faculty, Istanbul University-Cerrahpasa, Istanbul, Turke e-mail: tutuncumelih@yahoo.com 


\section{Servikal ve Jeneralize Distonide Periferik Sessiz Periyot}

Öz

Amaç: Distoni, sürekli veya aralıklı kas kasılmalarının anormal duruşlara veya tekrarlayan hareketlere neden olduğu istemsiz bir hareket bozukluğudur. Distoni sadece bir motor sistem hastalı̆̆ı değildir. Patofizyolojisinde, anormal sensorimotor entegrasyon yaygın olarak kabul edilmektedir. Diğer bir patofizyolojik açıklama, inhibitör yolaklardaki anormalliklerdir. Bu çalışmanın amacı, kutanöz stimülasyonu (CuSP) veya miks sinir stimülasyonunu (MnSP) takiben sessiz period (SP) kaydederek distonide, omurilikteki inhibitör yolakların durumunu araştırmaktır.

Yöntemler: Çalışmaya 23 distonili hasta dahil edildi. Ayrıca kontrol grubu olarak 19 sağlıklı denek mevcuttu. Yaş gruplar arasında benzerdi. ( $\mathrm{p}=0.092)$. CuSP ve MnSP, sırasıyla abdüktör pollicis brevis ve median sinir aracıllğıyla kaydedildi.

Bulgular: CuSP'nin bașlangıç latansı, süresi ve supresyon indeksi ile ilgili olarak, distoni hastaları ile sağlıklı bireyler arasında fark yoktu. MnSP'nin başlangıç ve bitiş latansları ayrıca süreleri, hastalar ve sağlıklı bireyler arasında farklı değildi. Segmental ve jeneralize distonili hastaların karşılaştırılması, jeneralize distoni hastalarında I2 supresyon indeksinin düşük olduğunu gösterdi (100.0'a karşs $86.7 \pm 21.4 \%$; $F=4.252,0.035$ ).

Tartışma: Jeneralize distonili hastalarda CuSP sırasında daha az supresyon görülürken, servikal distonili hastalarda sağlıklı deneklere benzerdi. Sonuçlarımız, spinal inhibitör devrelerin, sadece ilgili segmentin klinik tutulumu varsa daha az aktif olduğunu.

Anahtar kelimeler: Distoni, kutanöz sessiz dönem, Mikst sinir sessiz dönemi.

\section{INTRODUCTION}

Dystonia is a condition that is resistant to most medical treatments, which may affect almost all body parts due to various etiologies. It is a hyperkinetic movement disorder described by continuous or alternating muscle contractions causing unusual posture ${ }^{1}$. The contractions have similar features: abnormal twisting or repetitive movements. An involuntary movement that involves muscle often triggers dystonia. Also, contractions may develop in the muscles that should not participate in the activity during voluntary movement (overflow phenomenon) ${ }^{2}$.

The cutaneous silent phase (CuSP) is a powerful inhibition of EMG activity, due to exposure of the cutaneous nerve fibers in the fingers to relatively great intensity, painful electrical stimuli ${ }^{3}$. The electromyographic silent period generated by electrical stimulation of larger fibers is a mixed nerve silent period (MNSP). The electrophysiological principles and adaptive function of the CuSP, which is thought to be a spinal reflex consisting of afferent arc Adelta fibers, and efferent arc consisting of alpha motor neurons, have not been clarified yet. The CuSP is thought to represent the inhibitory part of the complex defensive reflex. It works with excitatory cutaneous withdrawal reflexes, which are used to pull the extremity from the painful stimulus 4 .

Various movement disorders such as dystonia and tremor have been studied in spinal cord injuries such as syringomyelia and intramedullary masses ${ }^{5,6}$. To date, various electrophysiological studies have been conducted in dystonia. Blink reflex (BR), BR recovery cycle; startle reflexes showed the hyperexcitability of the relevant circuits. The transcranial magnetic stimulation study showed that intracortical facilitation decreased during sensory manipulation. Dystonia is not just a motor system disease. Although the nociceptive pathways are normal, the activity of the somatosensory pathways has also been shown to increase. Besides, it was observed that the activity increased during the movement dystonia. This paper aims to evaluate the condition of nociceptive pathways in dystonia through MNSP and CuSP7,8. 


\section{SUBJECTS AND METHOD}

\section{Subjects}

23 patients (12 female, 11 male); 10 patients with cervical dystonia, and 13 patients with generalized dystonia were included in the study. Also, 19 healthy subjects (11 female, 8 male; $\mathrm{p}=0.711$ ) were included in the study as a control group. There were no similarities in terms of age. $(41.4 \pm 12.1$ vs $36.2 \pm 5.2$ years, $\mathrm{p}=0.092$ ).

We excluded all patients with diseases that prevent electrophysiological examinations or create contraindications for examinations and had any other neurological disease that may affect electrophysiological examinations.

The study was approved by İstanbul UniversityCerrahpaşa ethical committee at 21 May 2021 with decision number A-06 and the patients signed informed consent.

\section{METHOD}

Electrophysiological recordings were done using Neuropack Sigma MEB-5500 (Nihon Kohden, Tokyo, Japan) EMG device and silversilver chloride surface electrodes. Individuals were in a comfortable chair, which support the arm. The elbow joint was maintained at a $90^{\circ}$ angle while the hand was in a neutral position. The filters, examine time, and amplitude sensitivity were 30-10,000 Hz., $30 \mathrm{~ms} / \mathrm{div}$, and $200 \mu \mathrm{V}$, respectively.

Cutaneous silent period: Electrodes were positioned on abductor pollicis brevis (APB) in a belly-tendon configuration. Stimuli at 20 times the sensory threshold on the second finger (2f) were given at a random rate while APB muscle performed an isometric contraction $(40 \%$ of maximum EMG activity). Visual and audio feedback of EMG signals will be used to control muscle activity. Twelve consecutive recordings were rectified, amplified, and averaged.

Mean baseline EMG amplitude, CSP initiation latency, CSP terminate latency, CSP time, I1 duration, LLR onset and duration, and I2 duration were measured. Total CSP suppression index, I1 suppression index, and I2 suppression index were calculated.

Mixed nerve silent period: Electrodes were on APB muscle. The median nerve at the wrist was stimulated with an electrical stimulus 25\% above the supramaximal threshold of the stimulus intensity producing motor response. Visual and audio feedback of EMG signals will be used to control muscle activity. Twelve consecutive recordings were rectified, amplified, and averaged. Mean MNSP onset latency, MNSP end latency, MNSP duration were measured.

\section{Statistical Analysis}

We compared the CuSP and MNSP parameters between patients with study and control subjects as well as between patients with generalized dystonia and patients with segmental dystonia.

We first determined the homogeneity of the groups using the Shapiro-Wilk test. According to the homogeneity, we used the Mann-Whitney $\mathrm{U}$ test or t-test. For categorical values, we used the chi-square test. SPSS 22.0 (IBM Corp. Released 2013. IBM SPSS Statistics for Windows) was used for statistical analysis. The mean and standard deviation (SD) values of all obtained data were calculated. A p value $<0.05$ was considered significant.

\section{RESULTS}

Cutaneous silent period: There were similarities between patients with dystonia and healthy subjects in terms of onset latency, duration, and suppression index of CuSP (Table 1). I2 suppression index was lower in patients with generalized dystonia compared to patients with cervical dystonia (100.0 vs $86.7 \pm 21.4 \%$; $\mathrm{F}=4.252$, 0.035). The other comparisons were similar between patients with generalized and segmental dystonia. Figure 1 shows comparisons of I1 and I2 onset latencies. 
Table I: The comparisons of latency, duration, and suppression index of CuSP between patients with dystonia and healthy subjects

\begin{tabular}{|l|l|l|l|}
\hline CuSP & $\begin{array}{l}\text { Patients with } \\
\text { dystonia n=23 }\end{array}$ & Healthy & subjects n=19 \\
\hline I1 onset latency (ms) & $45.34 \pm 8.18$ & $43.66 \pm 3.21$ & 0.73 \\
\hline I1 end (LLR onset) & $56.18 \pm 16.10$ & $59.66 \pm 2.51$ & 0.71 \\
\hline latency (ms) & & & 0.41 \\
\hline I1 duration (ms) & $38.40 \pm 10.59$ & $38.27 \pm 10.21$ & 0.97 \\
\hline I2 onset latency (ms) & $76.93 \pm 12.74$ & $76.74 \pm 21.87$ & 0.66 \\
\hline I2 duration (ms) & $68.52 \pm 14.19$ & $75.66 \pm 11.17$ & 0.96 \\
\hline I2 suppression index & $93.66 \pm 15.91$ & $98.72 \pm 5.23$ & 0.21 \\
\hline (\%) & & & \\
\hline
\end{tabular}
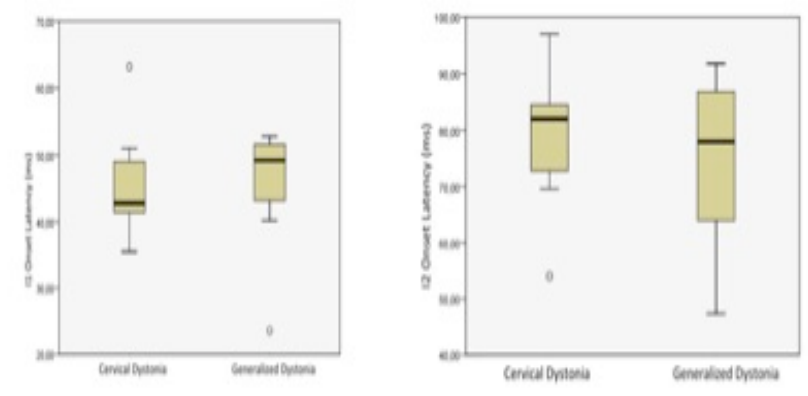

Figure 1: Comparisons of I1 and I2 latencies between patients with segmental and generalized dystonia.

Mixed nerve silent period: The initiation and terminate latencies of $\mathrm{MnSP}$, as well as its duration, were similar between patients and healty subjects and also between patients with generalized and segmental dystonia (Table 2 Figure 2).
Table II: Comparisons of duration, onset and end latencies between patients and healty subjects

\begin{tabular}{|l|l|l|l|}
\hline MNSP & Patients with & Healthy & $\mathrm{p}$ \\
\hline Onset latency (ms) & $25.6 \pm 17.0$ & $25.1 \pm 1.5$ & 0.398 \\
\hline End latency (ms) & $113.1 \pm 19.1$ & $110.6 \pm 11.6$ & 0.619 \\
\hline Duration (ms) & $87.8 \pm 19.4$ & $85.5 \pm 11.5$ & 0.667 \\
\hline
\end{tabular}
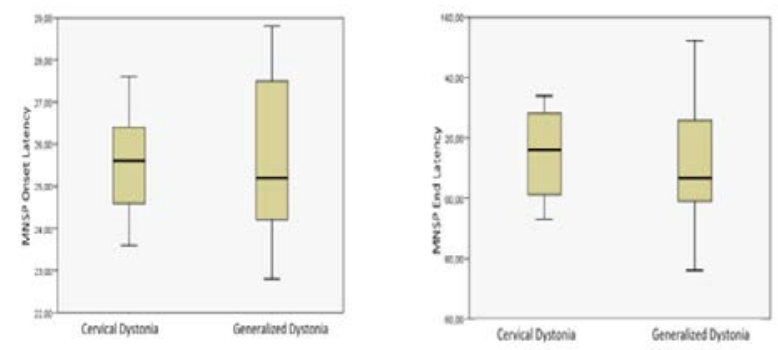

Figure 2: Comparisons of onset and end latencies between patients with segmental and generalized dystonia.

\section{DISCUSSION}

The most striking result to emerge from the data is that there was lower suppression during $\mathrm{CuSP}$ in generalized dystonia patients. However, the suppression index was similar between healty subjects and patients with dystonia.

CuSP is obtained after painful stimulation of a cutaneous nerve. CuSPs with withdrawal reflexes are protective responses. They are mediated in the spinal circuitry and the afferent pathway is formed by slow-conducting, highthreshold A-delta-type nociceptive fibers ${ }^{9}$.

CuSPs were studied in various movement disorders. CuSP was abnormal in essential tremor, multiple system atrophy, and Parkinson's disease ${ }^{10,11}$. It was normalized after administration of low-dose propranolol in essential tremor ${ }^{12}$. Levodopa did not normalize any of the abnormal CSP parameters in patients 
with multiple system atrophy whereas; a single dose of levodopa may decrease the CSP duration in in patients with Parkinson's disease ${ }^{13,14}$.

A previous study demonstrated patients with brachial dystonia had longer CuSP duration with no change in latency or suppression of EMG activity, very similar to that found in Parkinson's disease. Subsequent studies confirmed longer CuSPs in patients with organic or psychogenic dystonia. However, the latter study included mainly patients with brachial dystonia. Pallidal deep brain stimulation for upper limb dystonia did not change the CSP 15 .

The appearance of a CSP is dependent on intact small-diameter A-delta fibers and the onset latency is generated by the small-diameter Adelta fibers while inhibitory circuits in the spinal cord, supraspinal modulatory control, large-diameter afferents, and motor fibers contribute its duration and depth of the inhibition. Considering the reports in the literature, our results suggest that the depth of inhibition in spinal circuits mediating upper extremities is reduced in generalized dystonia compared to cervical dystonia.

Dystonia is a movement disorder characterized by continues or intermittent muscle contractions causing unusual, often repetitive, movements, postures, or both ${ }^{16}$. Abnormal plasticity, sensory dysfunction and also decreased inhibition are thought to take part in a vital role in the pathogenesis ${ }^{17}$. The characteristic examination findings in dystonia are motor overflow and abnormal contractions. In light of recent studies, dystonia is thought to occur as a result of network dysfunction. Aberrant overactivity is thought to arise from single-node dysfunction such as aberrant communication among the multiple nodes. These changes likely lead to abnormal reorganization and disinhibition at the brainstem and spinal cord level.
Similar to reduced inhibition found by this study, another brainstem and spinal reflex was previously reported to be excitable. Auditory startle response and startle response to sensorial inputs were exaggerated in generalized dystonia ${ }^{18}$. Flexor reflex that is a backdown to a harmful stimulus is a polysynaptic and multisegmental spinal reflex. It is activated by the nociceptive flexor reflex afferents. Flexor reflex or withdrawal reflex has not been examined in dystonia. Vibratory inhibition studied by $\mathrm{H}$ reflex, predominantly reflecting presynaptic inhibitory action, was depressed in levodopa responsive generalized dystonia reflecting the facilitation of the motor neuron pool at the spinal ${ }^{19}$.

The interesting part of our study is the lack of reduced inhibition in patients with cervical dystonia. If we considered the motor outflow, one of the characteristic signs in dystonia, one would expect to see reduced inhibition in both types.

Similarly, recovery of upper limb H-reflex was normal in electrophysphological studies of the author's cramps or blepharospasm. However, it has shown an increase in studies of spasmodic torticollis or generalized dystonia. In all the patient groups, the amount of reciprocal inhibition of the H-reflex decreased. Also facilitation of the H-reflex during the 3rd period of inhibition has been decreased in torticollis or patients with generalized dystonia ${ }^{20}$. Therefore, these authors concluded that there were abnormalities in clinically normal parts of the body even in focal or segmental dystonia.

The MnSP is less commonly investigated compared to CuSP in neurology practice. The MnSP is composed of a collision of antidromic and orthodromic impulses. It is mediated by Renshaw cell inhibition, which is triggered by antidromic motor impulses and stimulation of high-threshold cutaneous fibers inside in mixed nerve ${ }^{21}$. In paroxysmal kinesigenic dyskinesia, the duration of MnSP was shortened during the 
dyskinetic episode 22 . Because the third portion of the MnSP and CuSP fits to the same physiologic process, namely stimulation of thinly myelinated fibers inducing spinal interneuron oligosynaptic inhibition of motor neurons.

Several limitations to this study needed to be acknowledged. Firstly, these findings are limited by small sample size. And secondly, it is possible that these results were influenced by the lack of patients with brachial dystonia.

In conclusion, there was lower suppression during CuSP in generalized dystonia patients. However, the suppression indexes were similar between healthy subjects and patients with dystonia. Our results suggest that spinal inhibitory circuits are less active if only there is clinical involvement of the relevant segment.

Ethics Approval: The study was approved by İstanbul University-Cerrahpaşa ethical committee at 21 May 2021 with decision number A-06 and the patients signed informed consent.

Conflicts of Interest: The authors declare that they have no competing interest.

Financial Dislosure: There are no financial supports.

\section{REFERENCES}

1. Sanger TD. Chen D, Fehlings DL, Hallett M, et al. Definition and classification of hyperkinetic movements in childhood. Movement Disorders 2010; 25: 1538-49.

2. Sitburana O, Chen Wu LJ, Sheffield JK, Davidson A, Jankovic J. Motor overflow and mirror dystonia Parkinsonism and Related Disorders 2009; 15: 75861.

3. Gündüz A, Aydın Ş, Kızıltan ME. Cutaneous silent period: A literature review. Neurological Sciences and Neurophysiology 2020; 37: 101-9.

4. Kofler M, Leis AA, Valls-Solé J. Cutaneous silent periods - Part 2: Update on pathophysiology and clinical utility. Clinical Neurophysiology 2019; 130: 604-15.

5. Wang Y, Guo S, Xu L, et al. Tremor Caused by Dandy-Walker Syndrome Concomitant with Syringomyelia: Case Report and Review of the Literature Review. World Neurosurgery 2020; 136: 301-4.

6. Cohodarevic T, Mailis A, Montanera W, Abnormalities S. Syringomyelia: Pain, Sensory Abnormalities, and Neuroimaging. 2000; 1: 54-66.

7. Mulroy E, Balint B, Latorre A, et al. SyringomyeliaAssociated Dystonia: Case Series, Literature Review, and Novel Insights. Movement Disorders Clinical Practice 2019; 6: 387-92.

8. Raj VS. Lofton L. Rehabilitation and treatment of spinal cord tumors. Journal of Spinal Cord Medicine 2013; 36: 4-11.

9. Kofler M, Leis AA. Valls-Solé J. Cutaneous silent periods - Part 1: Update on physiological mechanisms. Clinical Neurophysiology 2019; 130: 588-603.

10. Han JK, Oh K, Kim BJ, et al. Cutaneous silent period in patients with restless leg syndrome. Clinical Neurophysiology 2007; 118: 1705-10.

11. Congiu P, Fantini ML, Milioli G, et al. F-Wave duration as a specific and sensitive tool for the diagnosis of restless legs syndrome/willis-ekbom disease. Journal of Clinical Sleep Medicine 2017; 13: 369-75.

12. Sonkaya AR, Şenol MG, Demir S, Özdağ FM. The investigation into the cutaneous silent period in patients with essential tremor pre-treatment and post-treatment. Acta Neurologica Belgica 2016; 116: 583-8.

13. Stetkarova I, Kofler M. Majerova V. Cutaneous silent periods in multiple system atrophy. Biomedical Papers 2015; 159: 327-32.

14. Pullman SL, Ford B, Elibol B, et al. Cutaneous electromyographic silent period findings in brachial dystonia. Neurology 1996; 46: 503-8.

15. Bocek V, Stetkarova I, Fecikova A, et al. Pallidal stimulation in dystonia affects cortical but not spinal 
inhibitory mechanisms. Journal of the Neurological Sciences 2016; 369: 19-26.

16. Fahn S. Concept and classification of dystonia. Advances in neurology 1988; 50: 1-8.

17. Quartarone A. Hallett M. Emerging concepts in the physiological basis of dystonia. Movement Disorders 2013; 28: 958-67.

18. Kiziltan ME, Gunduz A, Apaydin H, Ertan S, Kiziltan G,. Auditory startle reflex and startle reflex to somatosensory inputs in generalized dystonia. Clinical Neurophysiology 2015; 126: 1740-5.

19. Koelman JH, Speelman JD, Hilgevoord AA, Bour LJ, Ongerboer de Visser BW. Dopa-responsive dystonia and normalization of soleus H-reflex test results with treatment Neurology. 1995; 45: 281-5.

20. Panizza M, Lelli S, Nilsson J, Hallett M. H-reflex recovery curve and reciprocal inhibition of H-reflex in different kinds of dystonia. Neurology 1990; 40: 824-8.

21. Leis AA. Conduction abnormalities detected by silent period testing. Electroencephalography and Clinical Neurophysiology/ Evoked Potentials 1994; 93: 444-9.

22. Leis AA, Ross MA, Emori T, Matsue Y, Saito T. The silent period produced by electrical stimulation of mixed peripheral nerves. Muscle \& Nerve 1991; 14: 1202-8. 